\title{
On Gymnodactylus amarali Barbour, 1925, with the description of a new species (Sauria, Gekkonidae)
}

\author{
PAULO EMILIO VANZOLINI* \\ Museu de Zoologia, Universidade de São Paulo, USP, Cx. Postal 42694, 04299-970 São Paulo, SP, Brasil \\ Manuscript received on August 16, 2004; accepted for publication on August 18, 2004.
}

\begin{abstract}
Gymnodactylus amarali Barbour, 1925, was previously considered to be a subspecies of G. geckoides, with a wide distribution in the Brasilian cerrados. Examination of a specimen from Alto Parnaíba, Maranhão, near the type locality (Engenheiro Dodt, Piauí), indicates that it is a proper species, apparently limited to the upper Parnaíba basin. The form previously identified as G. geckoides amarali is described as a new species, G. carvalhoi, type locality Ipueiras, State of Tocantins, thus diagnosed: color pattern plain or, more often, with moderately contrasted ocelli; dorsal tubercles in 13 - 16 poorly organized longitudinal rows (mode 14, $72 \%) ; 31-49$ tubercles in a paramedian row; $17-22$ transverse rows of ventral scales; 13 - 18 infradigital lamellae on toe IV; tail longest in the genus. The new species is statistically compared to parapatric $G$. geckoides, widespread in the caatingas. Although only one meristic character (number of tubercle rows) is by itself diagnostic, the species are easily told apart. It is thought on provisional evidence that they are better considered for the time being as full species, not subspecies. A brief consideration is made of the speciation model that seems suitable, to wit, parapatric.
\end{abstract}

Key words: Speciation, Lizards, systematics.

\section{INTRODUCTION}

In a review of the genus Gymnodactylus (Vanzolini 1953) I once proposed that all specimens from the cerrados belonged to G. amarali Barbour, 1925 (then thought to be a subspecies of G. geckoides Spix, 1825), originally described from Engenheiro Dodt, Piauí, a town on the upper Rio Parnaíba, at the northeastern edge of the cerrados (Vanzolini 1976). Later (Vanzolini 1982) I felt dissatisfied with the scheme, and commented on the lack of critical materials. The main issue was thought to be the real nature of G. amarali. There being no authentic specimens of the form in Brasilian collections, I found it necessary to go to the type locality and try to obtain

\footnotetext{
*Member, Academia Brasileira de Ciências

E-mail:vanzo@usp.br
}

a sample capable of settling the problems of the group.

Engenheiro Dodt, founded in 1917 by a prospective agribusiness in Piauí (Iglesias 1951), is unobtrusively but explicitly present in current maps (including road maps) at 0848,4556 , on the right bank of the Rio Parnaíba, at the mouth of the tributary Riachão. Once one gets there, however, all that is seen is a derelict ruin, choked by vegetation, hard to reach, of which even the name has escaped regional memory. I tried there and got no specimens; however, at the town of Alto Parnaíba (some $35 \mathrm{~km}$ up river, to the south, on the opposite bank), one specimen was collected and, in spite of having torn dorsal skin, turned out to be sufficient to solve the problem. 
Description of $G$. amaral (MZUSP 93075, Alto Parnaíba, Maranhão), Fig. 3.

A juvenile (SVL $35 \mathrm{~mm}$ ), tail broken. Snout, seen from above, triangular, plane; canthus rostralis not sharp but evident. Top of the snout, in front of the level of the eyes, with flat coarse granules; behind that level with very fine granules interspersed with button-like small tubercles. Loreal region with granules similar to those on top of the snout. Supralabials four, large, diminishing posteriorly, bordered above by enlarged flat granules. Infralabials three, moderate, decreasing posteriorly. Nostril indenting the rostral, placed between the upper corner of the first labial, two small postnasals, and one larger, slightly swollen supranasal. Ear opening low, slitlike, pointing forward and down. Symphysial broad, irregular, in direct contact with the gulars, that are small, uniform, flat, imbricate.

Dorsal granules very small. Tubercles small, variable in shape and size, poorly aligned, in 10 irregular longitudinal rows. The skin is damaged, preventing the counting of tubercles in a paramedian row. By counting the number of tubercles in a stretch of intact skin $5 \mathrm{~mm}$ long, I calculated a total of 66 (see below). Ventrals sub - cycloid, rather regular, in 20 transverse rows at midbody. A narrow transverse patch of very small preanals.

Upper and anterior aspects of arm with large, smooth, well imbricated scales; otherwise granular, including the elbow. Anterior half of forearm with large smooth scales, remainder granular. Palm of hand finely granular. Fingers, in increasing order of length, I, (IV - V), (II - III). Lamellae regular, slightly swollen.

Front half of thigh and leg with flat, smooth, imbricate scales, posterior half granular. Plantar surface granular, with one row of slightly enlarged granules on each margin. Toes I, II, (III - IV - V). Lamellae as those of hand.

Base of tail dorsally with enlarged tubercles, distinctly keeled, poorly aligned with the dorsal ones. Ventral caudal scales (those present), like those of the trunk.

Dorsal parts ashy brown, with a reddish tinge on the head. A light band, from the nostril through the upper half of the eye, curving into the parietal region. Dorsum with four irregular series of very vivid ocelli, with thick, irregular black borders and a stark white center, usually coinciding with a dorsal tubercle. Ventral parts cream - colored.

\section{COMParison With Cerrado SAMPles}

The vegetation at Engenheiro Dodt (that was) and at Alto Parnaíba is cerrado. Biogeographically, both localities (Map 1) are on or near the edge of the domain, close to the transition to the caatingas. One must not forget (Ab'Sáber 1967, 2003) that transition between domains is never gradual, but a mosaic of fragments of the contrasting biomes. A first comparison of $G$ amarali must be made with the form widespread in the cerrados, that I have in the past called Gymnodactylus geckoides amarali and describe below as G. carvalhoi, sp. n.

I started (Appendix, Map 1) with 76 specimens from 13 localities in the domain of the cerrados. The most striking difference is in color pattern. Ocelli are common in Gymnodactylus (Vanzolini 2004; below; Figs. 1, 3, 4) but never as conspicuous and vivid as those of amarali, which, furthermore, center on dorsal tubercles. I consider this character (of course combined with the locality), sufficient to uphold the identification of the Alto Parnaíba specimen as amarali. In fact, color pattern is the only strong point in Barbour's original description, which is very sketchy, specially considering the morphological homogeneity of Gymnodactylus.

The few pholidotic differences I notice are: (i) amarali has a better defined canthus rostralis, with smaller loreals; (ii) the dorsal tubercles of amarali are weaker and much less well organized; (iii) the ear opening of carvalhoi is round (iv) carvalhoi has no preanal patch.

Finally, with regard to meristic characters, there is of course variation in the cerrados, which I discuss below, but Table I shows that, in spite of the meager statistical basis, the differences are unquestionable.

Estimation of number of tubercles in a para- 
TABLE I

Gymnodactylus amarali and carvalhoi, statistics of the distributions of frequencies, meristic characters. See text for definitions of carvalhoi geographic samples.

\begin{tabular}{|c|c|c|c|c|c|c|}
\hline Sample & & $\mathrm{N}$ & $\mathrm{R}$ & $\mathrm{m}$ & s & $\mathrm{V}$ \\
\hline \multicolumn{7}{|c|}{ Tubercle rows } \\
\hline amarali & & 1 & 10 & & & \\
\hline \multirow[t]{7}{*}{ carvalhoi } & A & 2 & $14-16$ & 15.0 & & \\
\hline & $\mathrm{B}$ & 7 & 14 & 14.0 & & \\
\hline & $\mathrm{C}$ & 20 & $13-15$ & $14.0 \pm 0.10$ & 0.5 & 3.2 \\
\hline & $\mathrm{D}$ & 19 & $13-15$ & $13.9 \pm 0.11$ & 0.5 & 3.3 \\
\hline & $\mathrm{E}$ & 5 & 14 & 14.0 & & \\
\hline & $\mathrm{F}$ & 2 & $13-16$ & 14.5 & & \\
\hline & $\mathrm{B}+\mathrm{C}+\mathrm{D}$ & 69 & $13-15$ & $13.9 \pm 0.06$ & 0.3 & 3.8 \\
\hline \multicolumn{7}{|c|}{ Tubercles in a paramedian row } \\
\hline amarali & & 1 & $(66)$ & $(66)$ & & \\
\hline \multirow[t]{7}{*}{ carvalhoi } & A & 2 & 40 & 40.0 & & \\
\hline & $\mathrm{B}$ & 7 & $37-45$ & $41.4 \pm 1.00$ & 2.6 & 6.4 \\
\hline & $\mathrm{C}$ & 15 & $32-43$ & $37.5 \pm 0.80$ & 3.1 & 8.3 \\
\hline & $\mathrm{D}$ & 12 & $31-46$ & $37.7 \pm 1.36$ & 4.7 & 12.5 \\
\hline & $\mathrm{E}$ & 3 & $40-43$ & 41.0 & & \\
\hline & $\mathrm{F}$ & 2 & $38-49$ & 43.5 & & \\
\hline & $B+C+D$ & 50 & $31-46$ & $37.7 \pm 0.53$ & 3.7 & 9.9 \\
\hline \multicolumn{7}{|l|}{ Ventrals } \\
\hline amarali & & 1 & 20 & 20 & & \\
\hline \multirow[t]{7}{*}{ carvalhoi } & $\mathrm{A}$ & 2 & 20 & 20.0 & & \\
\hline & $\mathrm{B}$ & 7 & $19-22$ & $20.3 \pm 0.42$ & 1.1 & 5.5 \\
\hline & $\mathrm{C}$ & 17 & 19-24 & $21.5 \pm 0.30$ & 1.2 & 5.7 \\
\hline & $\mathrm{D}$ & 12 & $17-23$ & $19.0 \pm 0.48$ & 1.9 & 9.8 \\
\hline & $\mathrm{E}$ & 3 & $21-22$ & 21.7 & & \\
\hline & $\mathrm{F}$ & 3 & $21-23$ & 22.3 & & \\
\hline & $B+C+D$ & 59 & $17-24$ & $20.0 \pm 0.22$ & 1.7 & 8.4 \\
\hline
\end{tabular}

\begin{tabular}{l|c|c|c|c|c|c}
\hline \multicolumn{1}{l}{ Fourth toe lamellae } \\
\hline amarali & & 1 & 14 & 14 & & \\
\hline carvalhoi & $\mathrm{A}$ & 2 & $18-21$ & 19.5 & & \\
\hline & $\mathrm{B}$ & 7 & $13-15$ & $14.0 \pm 0.31$ & 0.8 & 5.8 \\
\hline & $\mathrm{C}$ & 21 & $14-18$ & $15.6 \pm 0.32$ & 1.0 & 6.6 \\
\hline & $\mathrm{D}$ & 25 & $13-16$ & $14.4 \pm 0.21$ & 1.0 & 7.2 \\
\hline & $\mathrm{E}$ & 3 & 13 & 13.0 & & \\
\hline & $\mathrm{F}$ & 5 & $13-17$ & $15.0 \pm 0.71$ & 1.6 & 10.5 \\
\hline & $\mathrm{B}+\mathrm{C}+\mathrm{D}$ & 76 & $13-18$ & $14.7 \pm 0.12$ & 1.1 & 7.3 \\
\hline
\end{tabular}

Conventions: $\mathrm{N}$, individuals in sample. $\mathrm{R}$, range. $\mathrm{m}$, mean \pm its standard deviation. s, sample standard deviation. V, coefficient of variation. 


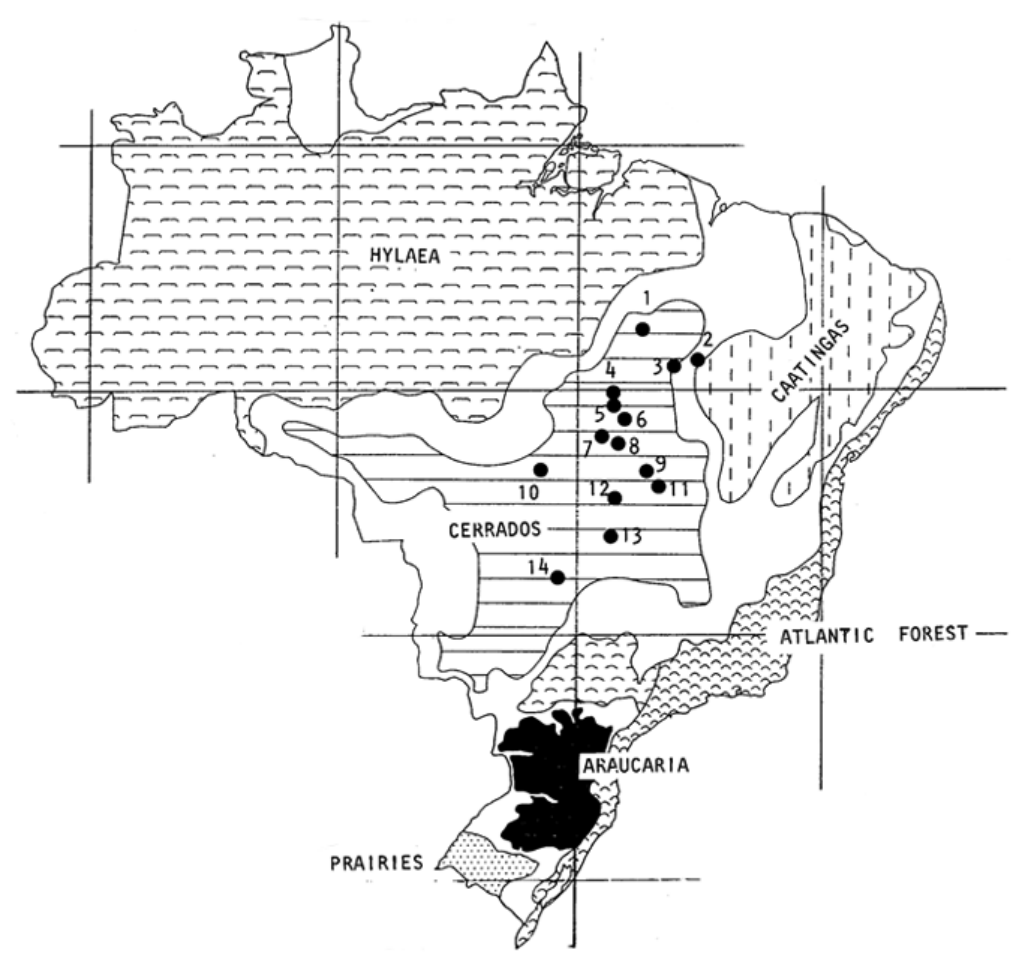

Map 1 - Localities of Gymnodactylus amarali and G. carvalhoi in the context of Ab'Saber's morphoclimatic domains of Brasil. Base map adapted from Ab'Saber (1967), with permission. (1) Carolina, Ma. (2) Engenheiro Dodt, Pi. (3) Alto Parnaíba, Ma. (4) Palmas, To. (5) Porto Nacional, To. (6) Ipueiras, To. (7) Gurupí, To. (8) Peixe, To. (9) Barra do São Domingos, To. (10) São Domingos, Rio das Mortes, Mt. (11) Posse, Go. (12) Serra da Mesa + Niquelândia, Go. (13) Pirenópolis, Go. (14) Rio Verde, Go.

median row in damaged specimens. I counted in 10 undamaged specimens the number of tubercles in $5 \mathrm{~mm}$ of skin, and multiplied the number of tubercles per millimeter by the length of the tubercle row.

There are in this procedure two irremovable sources of variance: the measurement of a $5 \mathrm{~mm}$ strip and, worse, the measurement of the length of the tubercle row, of which both end points involve considerable subjectivity (Vanzolini 2004). Thus, it is not surprising that the regression of the actual counts on the calculated values was not significant $(\mathrm{F}=1.509)$. The means, however, closely agreed $(\mathrm{t}=0.236, \mathrm{p}>0.80)$, so I propose that this method, though unsuitable for individual prediction, can be used for broad comparisons.

\section{Gymnodactylus carvalhoi, sp.n.}

Fig. 2

Holotype: MZUSP 91187, Ipueiras, Tocantins, 26-29.v.2002, ex MVA Planejamento e Consultoria Ambiental.

Paratypes: MZUSP 57017, Gurupí, Tocantins, 20.v.81, AMMRCosta. MZUSP 78244, Porto Nacional, Tocantins, 28.ix.90, ex Univ. Tocantins. MZUSP 87119 - 87121, Palmas, Tocantins, 1127.iii.98, M.E.V. Calleffo, ex Instituto Butantan. MZUSP 91183 - 91186, same data as holotype. MZUSP 91509 - 91511, Peixe, Tocantins, 38.vii.52, C. M. Carvalho and C. Castro-Mello, ex MVA. 

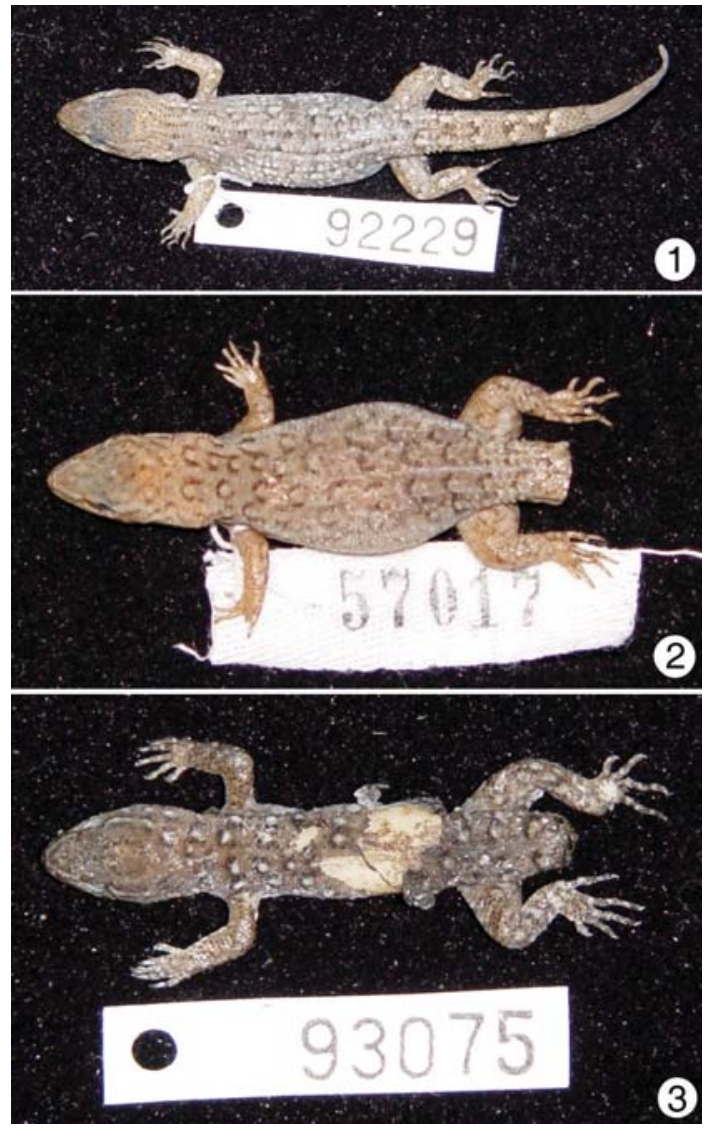

Fig. 1 - Gymnodactylus geckoides, MZUSP 92229, Salvador, BA. Fig. 2 - Gymnodactylus carvalhoi, sp.n., MZUSP 57017, Gurupí, TO. Fig. 3 - Gymnodactylus amarali, MZUSP 93075, Alto Parnaíba, MA.

\section{ETYMOLOGY}

Named after Celso Morato de Carvalho (Universidade Federal de Sergipe), old friend, colleague and field companion, who collected our specimen of Gymnodactylus amarali.

\section{DiAgnosis}

Color pattern plain or, more frequently, with moderately marked ocelli.

Meristic characters (Table I): Dorsal tubercles in 13 - 16 irregular rows (mode 14, 72\%); 31 - 49 tubercles in a paramedian row; $17-24$ transverse rows of ventral scales; 13 - 21 infradigital lamellae on the fourth toe.
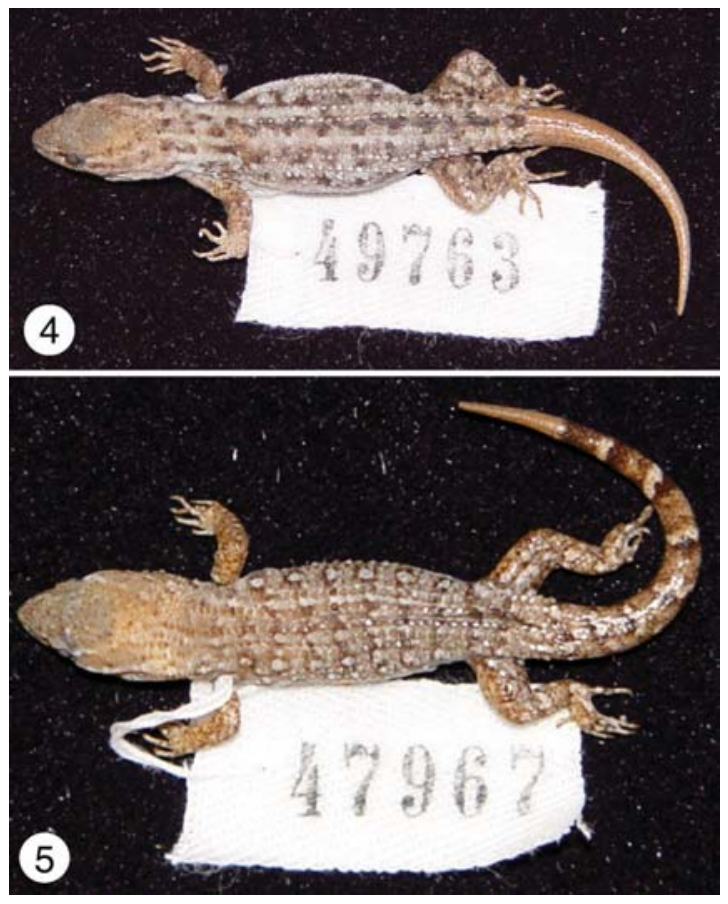

Fig. 4 - Gymnodactylus geckoides, MZUSP 49763, Exu, Pe; ocelli degenerated into longitudinal stripes. Fig. 5-MZUSP 47967, Exu, Pe; ocelli degenerated into short irregular transverse bars.

\section{DESCRIPTION}

Top of the snout moderately convex; in front of the level of the eyes covered with enlarged flat granules, behind that level with very fine granules interspersed with small button-like tubercles. Superciliary flap scaly, somewhat serrated. Rostral swollen, medianly incised. Nostril indenting the rostral, between the antero-superior tip of the first labial and two postnasals, not meeting the supranasal. Supralabials five, decreasing, reaching a little past the middle of the eye, followed by irregular granules. Ear opening small, round, approximately on the level of the rictus oris. Symphysial large, irregular, in contact with the gulars, which are small, flat, closely imbricate. Infralabials four, decreasing, the first separated from the symphysial by one triangular scale.

Dorsum with a background of very fine granules, and not very well-ordered longitudinal rows of keeled tubercles, with occasional gaps. Ventrals 
sub-cycloid. Ventral aspect of arm granular, otherwise with smooth imbricate scales. Forearm all scaly. Palm of hand granular. Infradigital lamellae slightly swollen, the rows on digits I and V prolonged on the margins of the hand. Thigh in front and below with smooth scales, otherwise granular. Leg ventrally with smooth imbricate scales, the remainder with small, irregular, sub-tubercular scales. Plantar surface granular; the rows of lamellae of toes I and $\mathrm{V}$ extending to the tarsus.

Intact tail dorsally with imbricate phylloid to triangular scales, in more or less regular transverse rows; ventral scales triangular, larger than the dorsals. Scales of the regenerated tail small, triangular, irregular, closely imbricate.

Color pattern variable from obsolete to, more frequently, ocellated. The ground color is ashy brown. Well-expressed ocelli have white centers and dark brown borders, often reduced to a halfmoon on the front half. The white centers may be reduced to barely noticeable whitish smudges.

On an opposite trend, ocelli may approach the amarali pattern, the black and white elements, however, never so striking, and the ocelli not centered on tubercles. Head with at most faint dark markings. Limbs unpatterned or with faint transverse dark bars. Tail vividly patterned, with $9-12$ transverse dorsal and ventral black bars, unconnected proximally, then coalesced into rings. The proximal black bars have overlaid stark white spots, extended into transverse bars after midlength of the tail. Tip of intact tail with a white spot. Regenerated portions of the tail uniform ashy brown. Belly light gray, often finely punctuated.

\section{GEOGRAPHICAL DIFFERENTIATION}

A statistical definition of G. carvalhoi has to take into account its obvious geographical variation.

\section{MATERIALS AND METHODS}

This work was started with 76 specimens from 13 localities in 4 Brasilian States, all in the morphoclimatic domain of the cerrados (Map 1; Appendix).
The area covered by the sampling is on the order of $500,000 \mathrm{sq} \mathrm{km}$.

There were at the beginning two very good one-locality samples, Barra do Rio S. Domingos, Tocantins, with 24 specimens, and Serra da Mesa, Goiás, with 23. All other samples were small, and not all specimens fully usable, so the assembling of geographical samples became necessary. The following scheme was adopted:

A Carolina, Maranhão (coordinates 0722, 4728), 2 specimens.

B Five localities on the middle Rio Tocantins, State of Tocantins, within a radius of ca. 150 km: Ipueiras, Palmas, Peixe, Porto Nacional and Gurupí (centroid 1055, 4835), 13 specimens.

C Barra do Rio S. Domingos, Tocantins (1243, 4718), 24 specimens.

D Serra da Mesa and Niquelândia, Goiás, localities ca. $15 \mathrm{~km}$ apart (centroid 1421, 4831), 27 specimens. After the preliminary phase of data collection and analysis, a large sample of uncatalogued specimens from Serra da Mesa became available. I extracted from it all 25 specimens with intact tails (also those with long regenerated tails, see below). I availed myself of the opportunity of checking my methods of scale counting by comparing the counts of these with samples from the same locality examined at different times. The respective values of $t$ were

\begin{tabular}{lcc}
\hline & $\mathrm{t}$ & $\mathrm{df}$ \\
\hline Tubercle rows & $0.752 \mathrm{~ns}$ & 39 \\
Tubercles in a paramedian row & $0.416 \mathrm{~ns}$ & 25 \\
Ventrals & $0.602 \mathrm{~ns}$ & 33 \\
Fourth toe lamellae & $0.120 \mathrm{~ns}$ & 46 \\
\hline
\end{tabular}

The two counts, made independently, and well apart in time, agreed most comfortably, and were fused as sample D for all purposes. 
E São Domingos, Mato Grosso $(1330,5124)$ on the Rio das Mortes, a tributary of the Rio Araguaia on its left bank, 5 specimens.

F Three localities in southern Goiás, within a radius of ca. $300 \mathrm{~km}$, Posse, Pirenópolis and Rio Verde (centroid 1555, 4924), 5 specimens.

All localities are in the domain of the cerrados. The variability of the composite samples is of the same order of magnitude as that of the singlelocality ones (Table I).

The characters studied were: (i) number of tubercle rows; (ii) number of tubercles in a paramedian row; (iii) number of transverse rows of ventrals; (iv) number of fourth toe lamellae; (v) relative tail length. These characters are discussed in Vanzolini (2004).

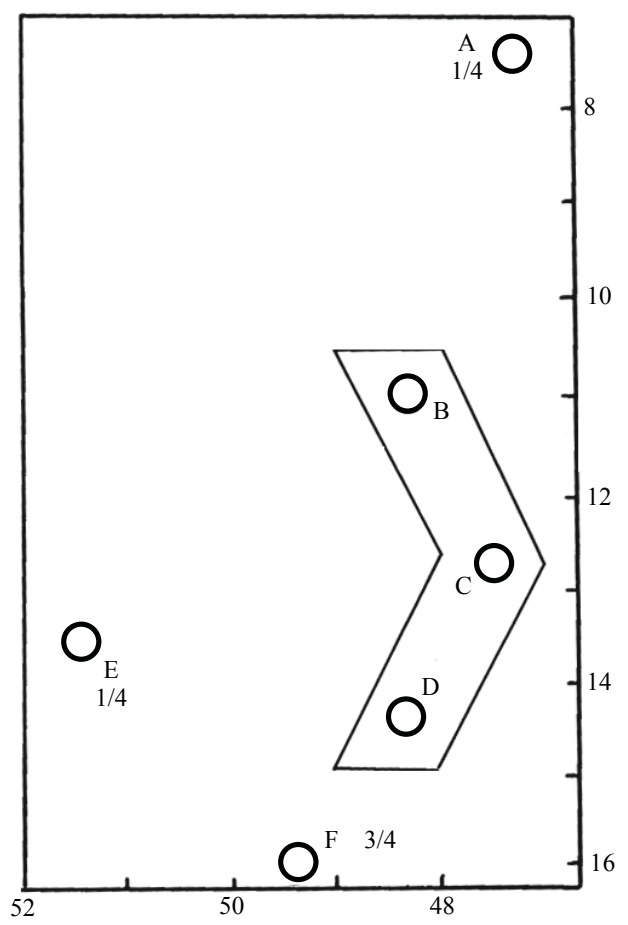

Graph 1 - Gymnodactylus carvalhoi. Skeleton map, inter-sample differences in meristic characters.

In order to get a synoptic view of the pattern, a skeleton map (Graph 1) was drawn, in which the localities are shown on a scatter plot, so that topological relationships are preserved independently of geographical details. Such maps can be drawn for individual characters, or for the ensemble, and several devices can be used to indicate agreement or disagreement between samples.

As it is my belief and practice, the statistical methods used were elementary and directly related to the nature of the variables. They can be found in textbooks, e.g. Dixon and Massey (1983), Zar (1999), Vanzolini (1993). The abbreviations adopted are explained at the foot of the respective tables.

\section{ANALYSIS}

Only three of the six geographical samples are large enough to permit the choice method, analysis of variance followed by Tukey's test. Instead, in order to compare simultaneously all samples, $\chi^{2}$ tests were performed, taking into consideration the contribution of each cell to the aggregate value of $\chi^{2}$. The results, as exemplified in Table II, were as follows:

\begin{tabular}{lccc}
\hline Character & $\chi^{2}$ & df & $\begin{array}{c}\text { Discrepant } \\
\text { samples }\end{array}$ \\
\hline Tubercle rows & $44.674 * *$ & 15 & $\mathrm{~A}, \mathrm{~F}$ \\
Tubercles in a & & & \\
$\quad$ paramedian row & $49.510^{* *}$ & 30 & $\mathrm{~F}$ \\
Ventrals & $65.974 * * *$ & 35 & $\mathrm{~F}$ \\
Lamellae & $45.440 * *$ & 25 & $\mathrm{E}$ \\
\hline
\end{tabular}

We have thus (Graph 1) a core of homogeneous samples in the valley of the Rio Tocantins, from central Tocantins (state) to northern Goiás. From this area I selected the hypodigm. Sample F, from southern Goiás, is the most divergent, 3 characters out of 4. Sample E, on the other side of the Araguaia, and sample A, in the far north, differ by one character each. The species is thus best defined, statistically, by the combination of samples B, C and D (Table I, Graph 1).

I checked the potential presence of correlations between the meristic characters and latitude, mean annual rainfall and mean annual temperature, and found none.

In relative tail length no sign of geographical 
TABLE II

G. carvalhoi, geographical differentiation, tubercle rows.

\begin{tabular}{|c|c|c|c|c|c|c|c|}
\hline & \multicolumn{6}{|c|}{ Samples } & \\
\hline Rows & A & B & $\mathrm{C}$ & $\mathrm{D}$ & $\mathrm{E}$ & $\mathrm{F}$ & sum \\
\hline 13 & 0 & 0 & 2 & 5 & 0 & 1 & 8 \\
\hline 14 & 1 & 7 & 16 & 33 & 5 & 0 & 62 \\
\hline 15 & 0 & 0 & 2 & 2 & 0 & 0 & 4 \\
\hline 16 & 1 & 0 & 0 & 0 & 0 & 1 & 2 \\
\hline sum & 2 & 7 & 20 & 40 & 5 & 2 & 76 \\
\hline
\end{tabular}

Contributions to $\chi^{2}$

\begin{tabular}{r|c|c|c|c|r}
\hline \multicolumn{1}{c|}{$\mathrm{A}$} & $\mathrm{B}$ & $\mathrm{C}$ & $\mathrm{D}$ & $\mathrm{E}$ & \multicolumn{1}{c}{$\mathrm{F}$} \\
\hline 0.2105 & 0.7368 & 0.0053 & 0.1480 & 0.5263 & 2.9605 \\
0.2445 & 0.2912 & 0.0061 & 0.0042 & 0.2080 & 1.6316 \\
0.1053 & 0.3684 & 0.8526 & 0.0053 & 0.2632 & 0.1053 \\
$\underline{17.0523}$ & 0.1842 & 0.5263 & 1.0526 & 0.1316 & $\underline{17.0526}$ \\
\hline
\end{tabular}

$$
\chi^{2}=44.674 * * * \quad d f=15
$$

differentiation was found. (see next section).

\section{STATUS OF G. carvalhoi}

At this point it becomes necessary to consider whether we have before us a set of species or subspecies. The decision is not trivial: to me, the subspecific status implies many fundamental theoretical aspects.

The differences between $G$. amarali and $G$. carvalhoi are important and, at least until better geographical coverage is available, I think it is advisable to consider them two good species. This is not so immediately clear in the case of G. geckoides. This form and G. carvalhoi are allopatric, but, at the nearest, no more than some $250 \mathrm{~km}$ apart (Map 2), not very far on the scale of South American geographical distributions. There are no decisive qualitative pholidotic differences between them: Gymnodactylus is, in this respect, a very homogeneous genus. Among the other three species of the genus there are pronounced differences in color pattern. G. amarali has been discussed above. G. darwinii has dark crossbars on the back and a characteristic nuchal band. G. guttulatus has a unique pattern of white round spots, sometimes with a faint outline of a brown border. G. geckoides and G. carvalhoi are very similar in color pattern (Figs. 2, 4, 5).

A medium-intensity pattern consists, in both G. geckoides and G. carvalhoi, of an ashy-brown background with ocelli. These have a white center, not quite as contrasting as that of G. amarali, and a darker or lighter border, often reduced to a half-moon in front. Variation in the direction of inconspicuousness is more frequent in G. carvalhoi, whose ocelli may be reduced to indistinct round white spots; more rarely one finds strongly expressed ocelli. In G. geckoides one may also find reduction of the brown border, with fine punctuations in the residual white spots. Frequent are specimens of G. geckoides with disorganized ocelli, resulting in short interrupted transverse dark brown bars (Fig. 5), more rarely in irregular longitudinal dark stripes, with no white left (Fig. 4).

In both forms there are occasional specimens with strongly marked ocelli, approaching the $G$. amarali condition, which stresses the essential homogeneity of the genus.

The main differences between the two forms lie in the meristic characters (Table III). In all three cases the differences are highly significant, but only 


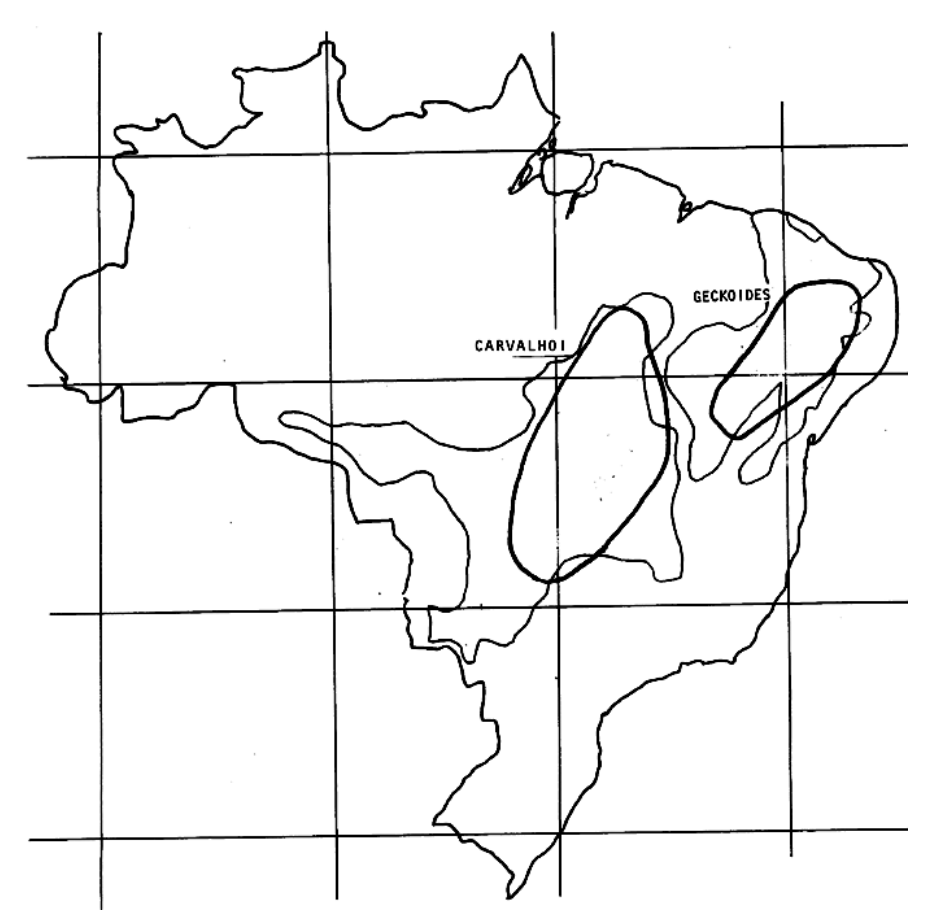

Map 2 - Distribution of Gymnodactylus geckoides and G. carvalhoi in the context of the cerrado and caatinga morphoclimatic domains. Base map adapted from Ab'Sáber (1967), with permission.

one character is by itself diagnostic: in fact my first clue to the identity of G. carvalhoi, the number of tubercle rows, 12 in all G. geckoides, 13 or more in G. carvalhoi.

\section{RELATIVE TAIL LENGTH}

A further comparison can be made, in spite of the scarcity of materials - that of relative tail length. Gekkonids are bad subjects for this type of study: their tails are fragile, frequently broken in collection specimens (over $80 \%$ in this case; see Appendix); breaks near the tip are impossible to detect, and add both bias and variance to the measurement. The only sample large enough for regression analysis is the improved (for the purpose) sample from Serra da Mesa. I started the analysis by looking for sexual or ontogenetic variation in it (Table IV). Analysis of covariance showed perfect homogeneity among (unsexed) juveniles, adult males and adult females; a joint regression was computed (Table IV, Graph 2).
No other sample of carvalhoi being suitable for comparison, all available tail lengths were plotted against the Serra da Mesa line (Graph 3). The differences observed are all within the range of the single-sample distribution, so I conclude that the presently available data do not indicate the presence of (at least) marked geographical differentiation in relative tail length of G. carvalhoi. A further joint regression (Table IV) was computed, comprising all specimens, and used to represent the species in interspecific comparisons.

G. carvalhoi was compared (Table III, Graph 4) with $G$. darwinii, represented by a good topotypical sample from Salvador, Bahia, and with $G$. geckoides, represented by a composite sample from Exu, Catinga do Moura and Paraíba, statistically very homogenous and covering well the geographical distribution of the form (Vanzolini 2004). Of $G$. guttulatus there were not enough materials.

Analysis of covariance shows that the lines of 


\section{TABLE III}

Gymnodactylus carvalhoi and G. geckoides, comparison of meristic characters.

\begin{tabular}{|c|c|c|c|c|c|c|}
\hline Species & $\mathrm{N}$ & $\mathrm{R}$ & $\mathrm{m}$ & $\mathrm{s}$ & $\mathrm{V}$ & $\mathrm{t}$ \\
\hline \multicolumn{7}{|c|}{ Tubercle rows } \\
\hline \multirow[t]{2}{*}{ geckoides } & 192 & 12 & 12 & & & \\
\hline & & & & & & $64.584 * * *$ \\
\hline carvalhoi & 76 & $13-16$ & $14.0 \pm 0.06$ & 0.4 & 3.0 & \\
\hline \multicolumn{7}{|c|}{ Tubercles in a paramedian row } \\
\hline \multirow[t]{2}{*}{ geckoides } & 192 & $37-52$ & $44.7 \pm 0.19$ & 2.7 & 5.9 & \\
\hline & & & & & & $14.434 * * *$ \\
\hline carvalhoi & 57 & $31-49$ & $38.2 \pm 0.52$ & 3.9 & 10.2 & \\
\hline \multicolumn{7}{|c|}{ Ventrals } \\
\hline \multirow[t]{2}{*}{ geckoides } & 203 & $18-24$ & $20.8 \pm 0.09$ & 1.2 & 5.8 & \\
\hline & & & & & & $3.170 * *$ \\
\hline carvalhoi & 68 & $17-24$ & $20.2 \pm 0.21$ & 1.7 & 8.4 & \\
\hline \multicolumn{7}{|c|}{ Lamellae } \\
\hline \multirow[t]{2}{*}{ geckoides } & 214 & $13-19$ & $15.7 \pm 0.08$ & 1.3 & 8.0 & \\
\hline & & & & & & $7.155^{* * *}$ \\
\hline carvalhoi & 86 & $13-18$ & $14.6 \pm 0.16$ & 1.1 & 7.6 & \\
\hline
\end{tabular}

Conventions as in Table I, plus $t$, Student's, significance of the difference between means.

TABLE IV

Gymnodactylus, statistics of the regression of tail length on body length.

\begin{tabular}{l|c|c|c|c|c|c|c}
\hline Sample & $\mathrm{N}$ & $\mathrm{R}(\mathrm{x})$ & $\mathrm{R}(\mathrm{y})$ & $\mathrm{b}$ & $\mathrm{a}$ & $\mathrm{F}$ & $\mathrm{r}^{2}$ \\
\hline carvalhoi & & & & & & & \\
\hline Serra da Mesa II j & 9 & $29-37$ & $33-48$ & $1.17 \pm 0.470$ & $2.7 \pm 3.02 \mathrm{~ns}$ & $6.227^{*}$ & 0.4708 \\
\hline$\sigma^{*}+$ & 8 & $40-47$ & $51-60$ & $1.14 \pm 0.370$ & $7.4 \pm 2.68^{*}$ & $9.574^{*}$ & 0.6147 \\
\hline $\mathrm{j} \sigma^{\top}+$ & 17 & $29-47$ & $33-60$ & $1.44 \pm 0.124$ & $-5.7 \pm 2.18^{* *}$ & $135.433^{* * *}$ & 0.9003 \\
\hline all & 27 & $29-49$ & $33-60$ & $1.28 \pm 0.077$ & $0.9 \pm 2.00 \mathrm{~ns}$ & $266.457^{* * *}$ & 0.9142 \\
\hline darwinii Salvador & 35 & $23-52$ & $24-66$ & $1.42 \pm 0.053$ & $-7.1 \pm 2.09^{* * *}$ & $721.832^{* * *}$ & 0.9562 \\
\hline geckoides all & 73 & $20-42$ & $23-53$ & $1.26 \pm 0.058$ & $-0.7 \pm 1.12 \mathrm{~ns}$ & $474.915^{* * *}$ & 0.8699 \\
\hline
\end{tabular}

Conventions: $\mathrm{N}$ - specimens in sample. $\mathrm{R}(\mathrm{x}), \mathrm{R}(\mathrm{y})$ - ranges of the variables. $\mathrm{b}$ - coefficient of regression \pm its standard deviation. $\mathrm{a}$ - intercept \pm its standard deviation. $\mathrm{F}$ - Fisher's quotient of variances (significance of the regression). $\mathrm{r}^{2}$ - coefficient of determination. ns - not significant at the $5 \%$ level. $*$ - significant at the $5 \%$ level. $* *$ - significant at the $1 \%$ level. $* * *$ - significant at the $0.1 \%$ level.

the three species may be considered parallel $(\mathrm{F}=$ $1.962,2 / 130 \mathrm{df})$, but that there is a barely significant difference in the intercepts $(\mathrm{F}=3.267,2 / 130 \mathrm{df})$. Tukey's test shows that G. carvalhoi, with longer tails, is the discrepant species, but the differences are very small.

\section{COMMENT}

As can be seen in Map 2, the presently known areas of distribution of the two forms do not overlap, do not even meet: they are separated by a gap some $250 \mathrm{~km}$ wide. This gap has not been explored for Gymnodactylus. Otherwise, given their extensive 


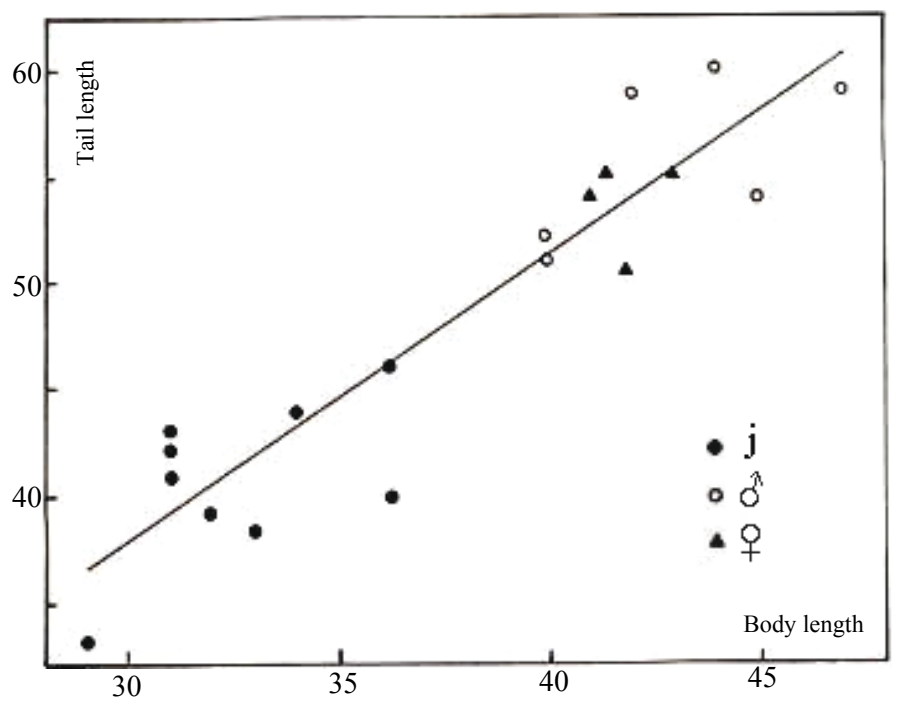

Graph 2 - Gymnodactylus carvalhoi. Regression of tail length on body length, Serra da Mesa, Go.

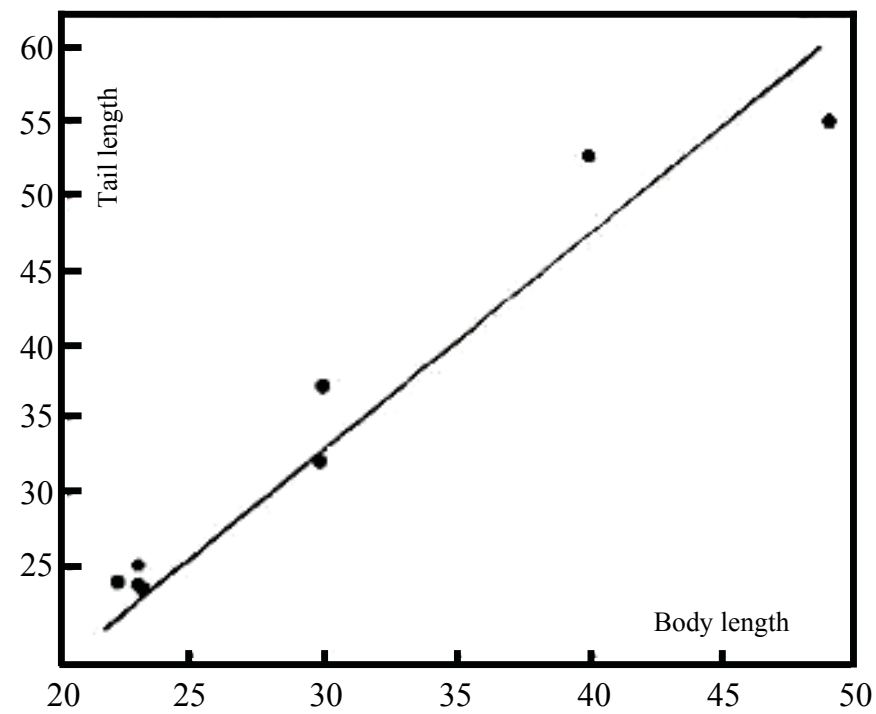

Graph 3 - Gymnodactylus carvalhoi. Regression of tail length on body length. Specimens from other samples plotted against the Serra da Mesa regression.

distribution in the caatingas and in the eastern cerrados, there is every reason to expect that the gap will be ultimately closed by further collecting. For practical purposes the two forms may be considered parapatric.

This geographical setting and the nature of the differences between $G$. carvalhoi and G. geckoides make it impossible to reject prima facie the hypothesis of two subspecies. This is the hypothesis I embraced in 1953, impressed by allopatry and by resemblance. These still impress me very much, but I now prefer to rely on intergradation. However, we 


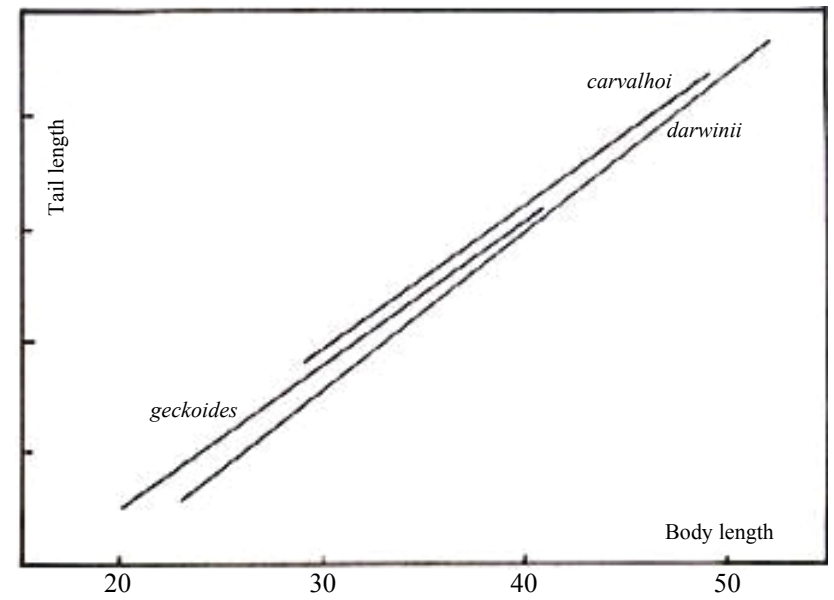

Graph 4 - Gymnodactylus, Regression of tail length on body length. Interspecific comparisons.

\section{GAZETTEER}

All latitudes South, all longitudes West.

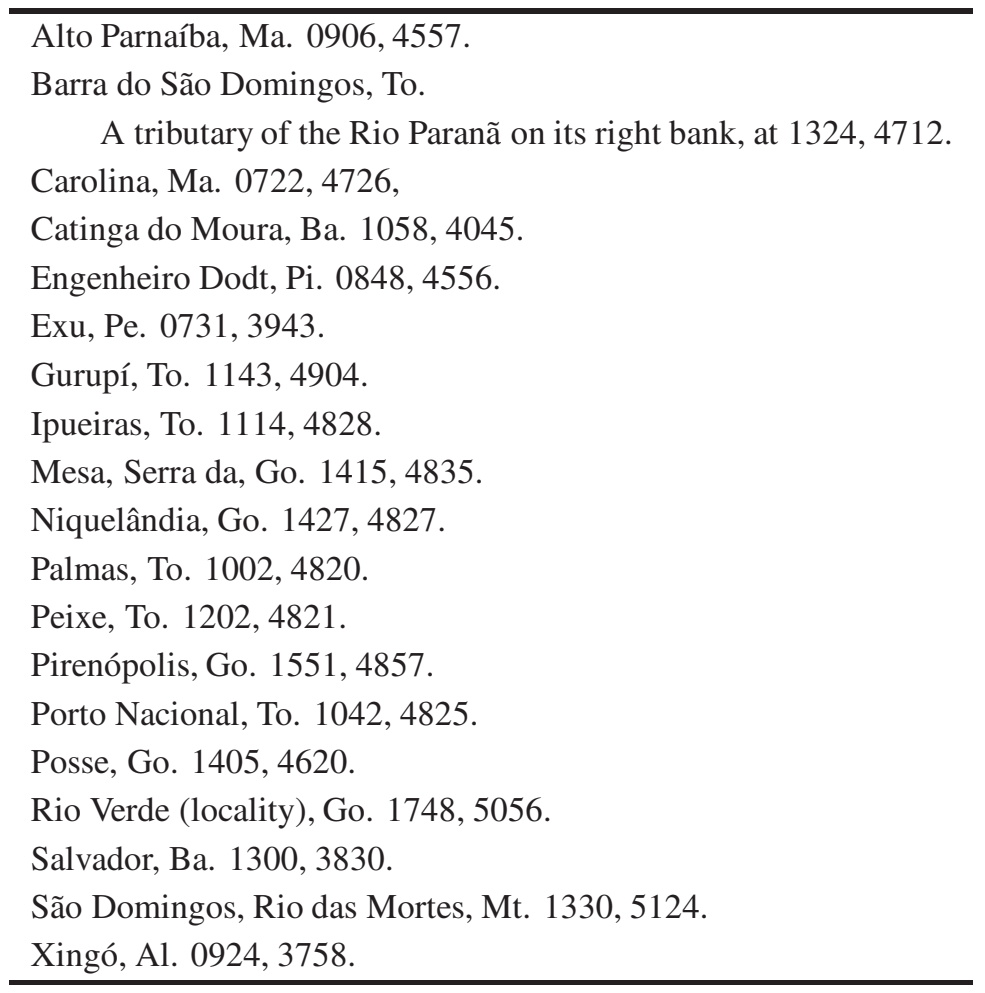

have no transect between the two areas, and it will not be easy to arrange for one. There are no roads, of whatever description, crossing from the western caatingas into the eastern cerrados.

One (admittedly weaker) alternative is to check the pattern of geographical differentiation of 
G. carvalhoi for suggestions of distributional structure compatible with intergradation. I can find none; anyway, the density of coverage is not promising. On this provisional, and acknowledgedly precarious basis, I keep (in the interest of caution and parsimony) the two forms for the time being as separate species.

\section{PROCESS}

Whether full species or subspecies, G. geckoides and G. carvalhoi are obviously closely related, sharing recent common ancestry, and we should inquire on the mechanism of differentiation. The study of speciation based on plain systematics involves advantages and disadvantages. Among the former are the ability to explore vast geographical and ecological spaces; among the latter are the usual unavailability of genetic information and, in many cases, the lack of natural history data. In the present case, the sampling is excellent, covering ca. $700,000 \mathrm{sq} \mathrm{km}$, representing much of the morphoclimatic domain of the caatingas and of the eastern half of the cerrados. There is conclusive evidence (Vanzolini 2003) that, in the species core area, in Tocantins, it has a decided preference for interfluvial cerrado, rather than for the other elements of the domains' landscape, gallery forest and backswamp.

In the circumstances, the preeminent fact is that two adjacent morphoclimatic domains are involved. When differentiation occurs within a domain, one is naturally led to a model of refuges, i.e., of past discontinuities in presently continuous ecologies, either of open or forested biomes (Vanzolini 1997, 2002). On the contrary, in the case of two adjacent domains, one has to have recourse to parapatric speciation.

There is a traditional distinction between sympatric and parapatric speciation (e.g., Via 2001, Gavrilets et al. 2000). The concepts are in fact different, as sympatry implies overlap of ranges, and parapatry specifically adjacency. From the viewpoint of speciation theory, however, the two concepts do not necessarily differ. The relevant feature for sympatric speciation (Mayr 1963) is "the origin of isolating mechanisms within the dispersal area of the offspring of a single deme". Since one of the populations has managed to colonize an adjacent area, the criterion is obviously fulfilled. This is especially true in the case of the Brasilian morphoclimatic domains, separated not by clinally arranged intermediate belts, but by mosaics of interdigitations, often amputated, resulting into minor enclaves of the contrasting biomes (Ab'Sáber 1967, 2003, Vanzolini 1974, 1976, 2002) and facilitating transit between them.

The theoretical basis of parapatric (sympatric) speciation is well established (e.g., Via 2001, Turelli et al. 2001, Church and Taylor 2002), but cannot be automatically extended to purely systematic studies, which must rest on the analysis of spatial and statistical patterns. I think in this regard the present study is well founded, and may be considered as evidence of the presence of the process in South America - a thing still to be desired (Turelli et al. 2001).

The novel feature of the case, from the South American viewpoint, is the presence of closely related forms specialized respectively to caatinga and to cerrado, in contradiction with the general pattern of absence of such specializations and prevalence of a common lizard fauna in the "diagonal of open formations" that aggregates caatingas and cerrados, southwest to the Chaco (Vanzolini 1976).

\section{POSTSCRIPT REGENERATED TAILS}

The Serra da Mesa sample afforded an opportunity of investigating a subject seldom dealt with, the potential of regeneration of the gekkonid tail. There are in the sample six adult specimens with relatively long but (inferring from the morphology of the scales) clearly regenerated tails. Their length varies from 75 to $83 \%$ of the length calculated by the regression equation for specimens of their body length. This is a considerable power of recuperation, but they all fall below the $5 \%$ confidence interval of the regression. 
APPENDIX

Gymnodactylus carvalhoi, raw data.

\begin{tabular}{|c|c|c|c|c|c|c|c|}
\hline \multirow[t]{2}{*}{ MZUSP } & \multirow[t]{2}{*}{ Locality } & \multirow[t]{2}{*}{ Sex } & \multirow[t]{2}{*}{ Length } & \multicolumn{2}{|c|}{ Tubercles } & \multirow[t]{2}{*}{ Ventr. } & \multirow[t]{2}{*}{ Lam. } \\
\hline & & & & trv. & lgt. & & \\
\hline 4006 & Barra do Rio S. Domingos, To & $\mathrm{j}$ & $38+x$ & 13 & - & 23 & 14 \\
\hline 4007 & $"$ & $\mathrm{j}$ & $37+x$ & 14 & 38 & 24 & 14 \\
\hline 4008 & $"$ & q & $40+x$ & 14 & 43 & - & 17 \\
\hline 4009 & $\overline{\prime \prime}$ & $\mathrm{j}$ & $36+x$ & 14 & - & 21 & 15 \\
\hline 4010 & $"$ & $\mathrm{j}$ & $29+x$ & 14 & 32 & 20 & 16 \\
\hline 4011 & $\overline{\prime \prime}$ & $\bar{j}$ & $30+42$ & 15 & 38 & 22 & 15 \\
\hline 4012 & $"$ & $\mathrm{j}$ & $36+x$ & 14 & - & 22 & 15 \\
\hline 4013 & $"$ & $\mathrm{j}$ & $33+x$ & 14 & - & - & - \\
\hline 4014 & $"$ & $\mathrm{j}$ & $28+x$ & 13 & 36 & 22 & 15 \\
\hline 4015 & $"$ & $\sigma^{x}$ & $36+x$ & - & - & - & 16 \\
\hline 4016 & $"$ & $\mathrm{j}$ & $23+x$ & 14 & 40 & 20 & 17 \\
\hline 4018 & $"$ & $\mathrm{j}$ & $30+37$ & 14 & 38 & 22 & - \\
\hline 4019 & $"$ & $\mathrm{j}$ & $33+35$ & 14 & 22 & 21 & 17 \\
\hline 4020 & $"$ & $\mathrm{j}$ & $21+36$ & 14 & 38 & 22 & 16 \\
\hline 4021 & ", & $\mathrm{j}$ & $26+x$ & 14 & - & 22 & 16 \\
\hline 4022 & $"$ & $\mathrm{j}$ & $38+x$ & - & - & - & 15 \\
\hline 4023 & $"$ & $\mathrm{j}$ & $27+x$ & 14 & 37 & - & 15 \\
\hline 4026 & $"$ & $\mathrm{j}$ & $23+x$ & 14 & 42 & 20 & 15 \\
\hline 4027 & $"$ & $\mathrm{j}$ & $22+x$ & 14 & 37 & 21 & 15 \\
\hline 4029 & $\overline{ }$ & $\mathrm{j}$ & $23+29$ & - & - & 22 & 16 \\
\hline 4030 & $"$ & $\mathrm{j}$ & $22+29$ & 14 & 36 & 19 & 15 \\
\hline 4031 & $"$ & $\mathrm{j}$ & $24+x$ & 15 & 33 & 22 & 15 \\
\hline 4032 & $"$ & 우 & $42+x$ & 14 & 39 & - & 18 \\
\hline 4033 & $"$ & $\mathrm{j}$ & $23+30$ & - & - & - & - \\
\hline 4052 & S. Domingos (Rio das Mortes), Mt & q & $42+x$ & 14 & 40 & 21 & 13 \\
\hline 4053 & 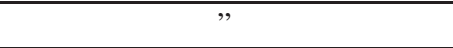 & $\sigma^{7}$ & $42+x$ & 14 & 40 & 21 & 13 \\
\hline 4053 & $"$ & $\mathrm{j}$ & $35+x$ & 14 & 43 & 22 & 13 \\
\hline 4054 & " & $\sigma^{2}$ & $43+x$ & 14 & - & 22 & 13 \\
\hline 4854 & $"$ & $\mathrm{j}$ & $22+x$ & 14 & - & - & - \\
\hline 7115 & Carolina, $\mathrm{Ma}$ & $\sigma^{2}$ & $41+x$ & 16 & 40 & 20 & 14 \\
\hline 7116 & " & $\mathrm{j}$ & $36+x$ & 14 & 40 & 20 & 15 \\
\hline 29617 & Rio Verde, Go & $\sigma^{2}$ & $42+x$ & 16 & 49 & 23 & 17 \\
\hline 56572 & Pirenópolis, Go & q & $46+x$ & 13 & 38 & 23 & 16 \\
\hline 57017 & Gurupí, To & 우 & $45+x$ & 14 & 41 & 21 & 14 \\
\hline 69394 & Posse, Go & $\sigma^{7}$ & $40+58$ & - & - & - & 15 \\
\hline 69395 & $"$ & $\sigma^{7}$ & - & - & - & 21 & 14 \\
\hline 69396 & " & 우 & - & - & - & - & 13 \\
\hline 77824 & Niquelândia, Go & $\mathrm{j}$ & $33+x$ & 14 & - & 17 & - \\
\hline 78244 & Porto Nacional, To & $\sigma^{7}$ & $46+x$ & 14 & 44 & 22 & 15 \\
\hline
\end{tabular}


APPENDIX (continuation)

\begin{tabular}{|c|c|c|c|c|c|c|c|}
\hline \multirow[t]{2}{*}{ MZUSP } & \multirow[t]{2}{*}{ Locality } & \multirow[t]{2}{*}{ Sex } & \multirow[t]{2}{*}{ Length } & \multicolumn{2}{|c|}{ Tubercles } & \multirow[t]{2}{*}{ Ventr. } & \multirow[t]{2}{*}{ Lam. } \\
\hline & & & & trv. & lgt. & & \\
\hline 87119 & Palmas, To & $\sigma^{7}$ & $49+60$ & 14 & 40 & 20 & 13 \\
\hline 87120 & " & $\mathrm{j}$ & $39+x$ & 14 & 41 & 21 & 13 \\
\hline 87121 & $"$ & 우 & $41+x$ & 14 & - & 22 & 14 \\
\hline 90093 & Niquelândia, Go & $\sigma^{7}$ & $45+54$ & - & 38 & 23 & 16 \\
\hline 90094 & " & 운 & $47+x$ & 13 & 37 & 19 & 15 \\
\hline 90095 & " & 우 & $45+x$ & 13 & - & - & 16 \\
\hline 91183 & Ipueiras, To & $\sigma^{\pi}$ & $41+x$ & 14 & 41 & 21 & 14 \\
\hline 91184 & " & $\mathrm{j}$ & $33+x$ & 14 & 37 & 20 & 13 \\
\hline 91185 & $"$ & $\mathrm{j}$ & $23+29$ & 14 & 41 & 22 & 14 \\
\hline 91186 & " & $\sigma^{\pi}$ & $43+x$ & 14 & 42 & 23 & 16 \\
\hline 91187 & $"$ & 우 & $48+x$ & 13 & 19 & 21 & 16 \\
\hline 91288 & Serra da Mesa, Go & $\sigma^{\pi}$ & $43+x$ & - & - & 14 & \\
\hline 91289 & " & $\sigma^{\pi}$ & $43+x$ & - & 32 & - & 14 \\
\hline 91290 & $"$ & $\sigma^{7}$ & $46+x$ & 14 & 31 & 18 & 13 \\
\hline 91292 & $"$ & 운 & $42+x$ & - & 43 & - & - \\
\hline 91293 & $"$ & $\sigma^{7}$ & $45+x$ & 14 & 42 & - & 16 \\
\hline 91294 & $"$ & $\sigma^{\pi}$ & $42+x$ & 14 & - & 18 & 14 \\
\hline 91295 & $"$ & $\sigma^{7}$ & $43+x$ & 14 & - & - & 15 \\
\hline 91296 & " & 우 & $48+x$ & 13 & - & - & 15 \\
\hline 91297 & Serra da Mesa, Go & 우 & $40+x$ & 14 & - & 17 & 14 \\
\hline 91298 & " & 우 & $45+x$ & - & - & - & 13 \\
\hline 91299 & $"$ & 운 & $48+x$ & 14 & - & 18 & 15 \\
\hline 91300 & $"$ & 우 & $47+x$ & 14 & 41 & 17 & 14 \\
\hline 91301 & $"$ & $\sigma^{7}$ & $41+x$ & - & 34 & 18 & 14 \\
\hline 91302 & $"$ & $\sigma^{\pi}$ & $40+x$ & 14 & - & - & 13 \\
\hline 91303 & $"$ & 우 & $48+x$ & 14 & 46 & 20 & 16 \\
\hline 91304 & $"$ & 우 & $42+x$ & - & - & - & 16 \\
\hline 91305 & $"$ & 우 & $41+x$ & 14 & - & 18 & 13 \\
\hline 91307 & $"$ & 우 & - & 14 & - & 20 & 14 \\
\hline 91308 & $"$ & 우 & $49+x$ & 14 & 34 & - & 14 \\
\hline 91309 & $"$ & 우 & $49+x$ & 15 & 36 & 19 & 14 \\
\hline 91310 & $"$ & $\sigma^{7}$ & $46+x$ & - & - & 21 & 14 \\
\hline 91311 & " & $\mathrm{j}$ & $33+x$ & 14 & - & - & 13 \\
\hline 91313 & " & 우 & $42+50$ & 14 & - & 22 & 14 \\
\hline 91509 & Peixe, To & 우 & $45+x$ & 14 & 42 & 19 & 14 \\
\hline 91510 & $"$ & $\sigma^{\pi}$ & $42+x$ & 14 & 45 & 19 & 14 \\
\hline 91511 & $"$ & $0^{x}$ & $45+x$ & 14 & 37 & 20 & 15 \\
\hline
\end{tabular}


APPENDIX (continuation)

\begin{tabular}{|c|c|c|c|c|c|c|c|}
\hline \multirow[t]{2}{*}{ MZUSP } & \multirow[t]{2}{*}{ Locality } & \multirow[t]{2}{*}{ Sex } & \multirow[t]{2}{*}{ Length } & \multicolumn{2}{|c|}{ Tubercles } & \multirow[t]{2}{*}{ Ventr. } & \multirow[t]{2}{*}{ Lam. } \\
\hline & & & & trv. & lgt. & & \\
\hline \multicolumn{8}{|c|}{ Uncatalogued sample } \\
\hline \multicolumn{8}{|c|}{ Field number } \\
\hline 33594 & Serra da Mesa, Go & $\mathrm{j}$ & $38+40$ & 14 & - & - & 14 \\
\hline 33870 & $"$ & $\mathrm{j}$ & $37+48$ & 13 & 40 & 21 & 14 \\
\hline 34022 & $"$ & $\bar{j}$ & $29+33$ & 13 & 36 & 19 & 13 \\
\hline 34066 & $"$ & 아 & $41+54$ & 15 & - & 22 & 14 \\
\hline 35062 & $"$ & $\sigma^{\pi}$ & $44+60$ & 14 & - & 19 & 14 \\
\hline 35082 & $"$ & $\sigma^{7}$ & $40+52$ & 15 & 39 & 19 & 14 \\
\hline 35145 & $"$ & $0^{n}$ & $46+49 *$ & 14 & 35 & 20 & 14 \\
\hline 35584 & $"$ & $\bar{j}$ & $31+42$ & - & - & - & - \\
\hline 35824 & $"$ & $\mathrm{j}$ & $31+43$ & 14 & 33 & 21 & 14 \\
\hline 36514 & $"$ & $0^{x}$ & $47+59$ & 14 & 37 & 19 & 14 \\
\hline 36528 & $"$ & $\sigma^{x}$ & $44+45^{*}$ & 14 & 34 & 18 & 14 \\
\hline 36562 & $"$ & $\mathrm{~J}$ & $39+39$ & - & - & - & - \\
\hline 36939 & $"$ & $\mathrm{~J}$ & $34+44$ & 15 & 36 & 29 & 14 \\
\hline 38217 & $"$ & $0^{x}$ & $42+54$ & 14 & 34 & 19 & 14 \\
\hline 39192 & $"$ & $0^{x}$ & $40+51$ & 14 & 33 & 20 & 14 \\
\hline 39817 & $"$ & $\bar{j}$ & $35+40$ & 14 & - & 19 & 15 \\
\hline 40026 & $"$ & $\bar{j}$ & $31+41$ & 15 & 35 & 21 & 14 \\
\hline 40283 & $"$ & 아 & $42+41 *$ & 15 & 44 & 18 & 14 \\
\hline 40921 & $"$ & $\bar{j}$ & $35+46$ & 13 & - & 19 & 15 \\
\hline 43983 & $"$ & 우 & $42+55^{*}$ & 13 & 34 & 19 & 14 \\
\hline 44308 & $"$ & 우 & $42+43^{*}$ & 15 & - & 18 & 14 \\
\hline 44388 & $"$ & $\bar{j}$ & $33+38$ & 14 & 37 & 18 & 13 \\
\hline 46627 & $"$ & ㅇ & $43+55$ & 15 & 43 & 21 & 14 \\
\hline 46635 & $"$ & $0^{x}$ & $42+48$ & - & - & - & 16 \\
\hline 47922 & $"$ & $\sigma^{\pi}$ & $43+44^{*}$ & 14 & 38 & 18 & 14 \\
\hline
\end{tabular}

Abbreviations. Length, body + tail. Tubercles, trv., transversely counted at midbody; lgt., in a paramedian row. Ventr., ventral scales, transversely counted at midbody. Lam., fourth toe lamellae. *Tail regenerated.

\section{ACKNOWLEDGMENTS}

I thank Celso Morato de Carvalho and Jeane Carvalho Vilar (Universidade Federal de Sergipe) for companionship in the trip to Engenheiro Dodt looking for G. amarali. Carolina Castro-Mello helped at all stages and took the digital photographs. Maria da Conceição Bueno da Silva, of the Museum Library, scanned all the illustrations. MVA Planejamento e Consultoria Ambiental donated the lizards from Tocantins. William Ronald Heyer (National Museum of Natural History, Washington, DC), Charles W. Myers (American Museum of Natural History, New York), Celso Morato de Carvalho and Francisca Carolina do Val (Museu de Zoologia, USP) profitably criticized an early version of the manuscript. This work was not supported by any granting agency.

\section{RESUMO}

Gymnodactylus amarali vem sendo considerada uma subespécie de G. geckoides amplamente distribuida nos 
cerrados brasileiros. Exame de um exemplar de Alto Parnaíba, Maranhão, localidade próxima da localidade tipo, Engenheiro Dodt, Piauí, indica que se trata de uma espécie válida, aparentemente limitada ao Alto Parnaíba. A forma anteriormente identificada como Gymnodactylus geckoides amarali é aqui descrita como Gymnodactylus carvalhoi, sp. n., assim diagnosticada: padrão de colorido dorsal obsoleto ou, mais frequentemente, com ocelos de expressão moderada; 13 - 16 (moda 14, 72\%) fileiras longitudinais, pouco regulares, de tubérculos dorsais; 31 - 49 tubérculos em uma fileira para - mediana; 17 - 22 fileiras transversais de escamas ventrais; 13 - 18 lamelas infradigitais no $4^{\circ}$ artelho; cauda (pouca coisa) mais longa do gênero. A nova espécie é estatisticamente comparada a G. geckoides, extensivamente distribuída nas caatingas; há acentuadas diferenças em todos os caracteres merísticos, mas apenas um deles (número de fileiras de tubérculos) é por si mesmo diagnóstico. Propõe-se, em caráter provisório, por questão de cautela e parcimônia, considerar as duas formas como boas espécies. Breve consideração é feita do modelo de especiação julgado mais provável, o parapátrico.

Palavras-chave: Especiação, Lagartos: sistemática.

\section{REFERENCES}

AB'SÁBER AN. 1967. Domínios morfoclimáticos e províncias fitogeográficas do Brasil. Orientação (Departamento de Geografia da Universidade de São Paulo) 3: 45-48.

AB'SÁber AN. 2003. Os dominios de natureza no Brasil. São Paulo: Ateliê Editorial, 159 p.

BARbour T. 1925. New Neotropical lizards. Proc Biol Soc Washington 38: 101-102.

CHURCH SA AND TAYLOR DR. 2002. The evolution of reproductive isolation in spatially structured populations. Evolution 56: 1859-1862.

DiXON WJ AND MASSEY FJ. 1983. Introduction to statistical analysis. $4^{\text {th }}$ ed., New York, USA. McGraw Hill. $\mathrm{xv}+678 \mathrm{p}$.

Gavrilets S, Li H And Vose MD. 2000. Patterns of parapatric speciation. Evolution 54: 1126-1134.

IGLESIAS FA. 1951. Caatingas e chapadões (Notas, impressões e reminiscências do Meio Norte brasileiro). São Paulo: Companhia Editora Nacional. Brasiliana 27: $x x v+638 p$.
MAYR E. 1963. Animal species and evolution. Cambridge, Mass. The Belknap Press of Harvard University. xiv +797 p.

TURelli M, Barton NH AND COYNe JA. 2001. Theory and speciation. Trends Ecol Evol 16: 330343.

VANZOLINI PE. 1953. Sôbre a diferenciação geográfica de Gymnodactylus geckoides (Sauria, Gekkonidae). Papéis Avulsos Zool 11: 225-262.

VANZOLINI PE. 1974. Ecological and geographical distribution of lizards in Pernambuco, northeastern Brasil. Papéis Avulsos Zool 28: 61-90.

VANZOLINI PE. 1976. On the lizards of a cerradocaatinga contact: evolutionary and zoogeographical implications. Papéis Avulsos Zool 29: 111-119.

VANZOLINI PE. 1982. A new Gymnodactylus from Minas Gerais, Brasil, with remarks on the genus and on montane endemisms in Brasil (Sauria, Gekkonidae). Papéis Avulsos Zool 34: 403-413.

VANZOLINI PE. 1993. Métodos estatísticos elementares em sistemática zoológica. São Paulo. Editora Hucitec, 130 p.

VANZOLIni E. 1997. The silvestrii species group of Amphisbaena, with the description of two new Brasilian species (Reptilia: Amphisbaenia). Papéis Avulsos Zool 40: 65-85.

VANZOLINi PE. 2002. A second note on Amphisbaena fuliginosa L., 1758 (Squamata, Amphisbaenidae), with a consideration of the forest refuge model of speciation. An Acad Brasil Cienc 74: 609-648.

VANZOLINI PE. 2003. A contribution to the ecogeography of the Brasilian cerrados. Biol Geral Exper 4: 3-10.

VANZOLINI PE. 2004. On the geographical differentiation of Gymnodactilus geckoidrs Spix, 1825 (Sauria, Gekkonidae): speciation in the Brasilian caatingas. An Acad Bras Cienc 76: 663-698.

VIA S. 2001. Sympatric speciation in animals: the ugly duckling grows up. Trends Ecol Evol 16: 381-390.

ZAR JH. 1999. Biostatistical analysis. $4^{\text {th }}$ ed. Upper Saddle River, New Jersey, USA. Prentice-Hall. xii + $663 \mathrm{p}$. 